\title{
The relation between teacher self-reported individualization and student-perceived teaching quality in linguistically heterogeneous classes: an exploratory study
}

\author{
Axinja Hachfeld ${ }^{1} \cdot$ Rebecca Lazarides $^{2}$
}

Received: 26 November 2019 / Revised: 20 August 2020 / Accepted: 24 August 2020 / Published online: 29 October 2020

(C) The Author(s) 2020

\begin{abstract}
Germany historically responded to student diversity by tracking students into different schools beginning with grade 5. In the last decades, sociopolitical changes, such as an increase in "German-as-a-second-language" speaking students (GSL), have increased diversity in all tracks and have forced schools to consider forms of individualization. This has opened up the scientific debate in Germany on merits and limitations of individualization for different student groups within a tracked system and heterogeneous classes. The aim of the present exploratory study was to examine how individualized teaching (i.e., teacher selfreported individualized teaching practices and individual reference norm orientation) is related to student-perceived teaching quality. Additionally, we considered moderation effects of classroom composition in relation to achievement and proportion of GSL students. Longitudinal data came from 35 mathematics classes with 659 9th and 10th grade students. Results showed significant relation between teacher self-reported individualized teaching practices and individual reference norm orientation and monitoring. Regarding the composition effects, the proportion of GSL students in class moderated the relation between teacher self-reported individual reference norm orientation and cognitive activation. Our findings contribute to the growing body of evidence that classroom composition can differentially impact the relation between teachers' behaviors and students' perceptions of teaching quality.
\end{abstract}

Axinja Hachfeld and Rebecca Lazarides contributed equally to this work.

Electronic supplementary material The online version of this article (https://doi.org/10.1007/s10212-02000501-5) contains supplementary material, which is available to authorized users.

Axinja Hachfeld

axinja.hachfeld@uni-konstanz.de

1 Binational School of Education, University of Konstanz \& Pädagogische Hochschule Thurgau, Constance, Germany

2 Department of Education, University of Potsdam, Potsdam, Germany 
Keywords Teaching quality $\cdot$ Individualization $\cdot$ Non-native speakers $\cdot$ Composition effects

Germany has traditionally responded to student diversity-especially regarding achievement, interests, and motivation-by tracking students into school types with different learning goals, school curricula, and support structures. The underlying assumption of this structural strategy was that students could best be supported by homogenizing the classes as much as possible based on prior achievement. The tracking decision that sets the path for a child's further educational development is taken generally in fourth grade when children are around 10 years of age. High-achieving students usually are allocated in academic track schools, labelled as gymnasium, which last 2 years longer than the other school forms and open the opportunity to go on to college and university. Students with lower grades continue with integrated secondary school education which-after graduation-is usually followed by vocational training. Some federal states still separate secondary schools further into lower secondary schools ("Hauptschule") and higher secondary schools ("Realschule"). Students with physical or learning disabilities or strong socioemotional impairments were historically sent to separated special education schools. The same applied and still applies for students with very low knowledge of German, who are often taught in separated classrooms until they are fluent enough in German to follow regular instruction (Massumi et al. 2015).

In the last decade, three major developments have forced the school system to change this approach based on structural differentiation and to focus on individualization within classes: First, after the first PISA study had shown that students in the lower track schools ("Hauptschule") reached substantially lower competencies than students in other school forms, new school forms were established in which low- and high-achieving students learn together also requiring a high level of individualization in class (Baumert et al. 2017); second, the ratification of the UN Convention on the Rights of Persons with Disability required the school system to admit students with physical, learning, or socioemotional impairments (Federal Ministry of Labour and Social Affairs 2011); and third, an increase in the percentage of students with non-native German language occured within the last decade (Autorengruppe Bildungsberichterstattung 2016, 2018). All three factors have resulted in an increase of diversity within individual schools and have opened up the debate in Germany about challenges and opportunities of individualization of learning processes (Dumont 2019). While all school curricula explicitly refer to the importance of individualized support, only few elaborated on a definition and on how this should be implemented (Dumont 2019). It is therefore not surprising that teachers often do not feel prepared enough to apply methods of individualization (Solzbacher 2008, for international findings see Anderson et al. 2012; Connor 2017; Dee 2010).

While some researchers and policy makers see individualization as a crucial strategy to overcome educational inequalities (Dräger 2009; Yeh 2010), other researchers have cautioned this conclusion (cp. Dumont 2019; Klieme and Warwas 2011). Instead, they refer to the importance of the overlaps between individualization and teaching quality, which are both known to be important influences on students' academic development (i.e., Fauth et al. 2014; Kunter et al. 2013). In this context, Klieme and Warwas (2011) have, for example, posed the question how individualization and teaching quality are related and if they could be sides of the same coin. The empirical investigation if individualization is related to or has an effect on how students perceive teaching quality is still outstanding. The present study is a first exploratory step toward shedding light on the relation between individualization and teaching quality. As theoretical foundation, we draw on the "offer-and-use" model which 
postulates that the relations between teachers' professional competence and student-perceived teaching quality vary depending on contextual variables such as the classroom composition (Helmke 2003). Since Germany has been facing an increase in non-native German speaking students, our study specifically focused on language-related classroom composition as a potential moderator.

\section{Individualization: individualized teaching practices in class and individual reference norm orientation}

According to Algozzine and Anderson (2007), a differentiated and individualized approach to instruction aims to maximize capabilities of all students by aligning the learning environment according to students' abilities, learning preferences, prior knowledge, and interests. Individualization can be seen as a holistic strategy including a great variety of instructional practices that aim to foster students based on their individual strengths and weaknesses (Corno and Snow 1986; Dumont 2019).

In previous studies, different forms of individualization have been positively associated with teacher-student relationships (Opdenakker and Van Damme 2006). For the German context, findings suggest that teachers generally do not individualize much and use only few forms of individualized teaching (Martschinke 2015). This finding might be explained by the lack of training on individualization that teachers have received so far and by a lack of common understanding of individualization on school curricular level (Dumont 2019).

In our study, we focus on two central dimensions of individualization: individualized teaching practices and individual reference norm orientation. Individualized teaching practices are similar to the concept of differentiated instruction (McTighe and Brown 2005) and refer to teaching strategies that consider students' individual strengths and weaknesses by implementing individualized teaching methods and tasks or by individualizing materials, required time on task, learning goals, level of difficulty, or learning content (Brüning and Saum 2010). Although such strategies show only weak effects on students' competencies (Hattie 2009), they might be a way to address students' individual needs and thus to enhance their feelings of support in class (Paradies and Linser 2008).

Another aspect of individualization refers to the reference norm orientations that teachers apply when teaching, giving feedback, or evaluating their students. In this study, we focus on individual reference norm orientation that refers to teacher evaluations of student achievement based on past performances of the specific student. An individualized approach to teaching requires an individual reference norm orientation. If teachers know what their students can do on their own and where they need support, they can meet them at their-what Vygotsky (1978) calls- "zone of proximal development" and assist them in achieving learning goals they would not yet achieve unassisted. This approach has also been discussed under the header of scaffolding, key characteristics of which are diagnosis and responsiveness (Smit et al. 2013).

Taken together, individualized instruction manifests itself in instructional behaviors; for example, by providing students with different materials, tasks, or learning goals depending on their individual characteristics (i.e., ability level). In addition, teachers' individual reference norm orientations are another aspect of individualization that should be perceived as such by the students. In our exploratory study, we examined how teacher 
self-reported individualized teaching practices and their self-reported individual reference norm orientation are related to student-perceived teaching quality depending on language-related classroom composition. We further assume that both concepts might be interrelated as teachers who provide individualized tasks to their students might also focus more strongly on their students' individual accomplishments on such tasks (e.g., compared with students' prior individual achievement on similar tasks).

\section{Teaching quality}

Previous research differentiates between three basic aspects of teaching quality: cognitive activation, classroom management, and social support (Klieme et al. 2009). Studies that refer to this definition of teaching quality show that high teaching quality is associated with students' achievement (Baumert et al. 2010; Decristan et al. 2017; Levpušček and Zupančič 2008; Lipowsky et al. 2009), subject-related interest (Fauth et al. 2014; Kunter et al. 2007; Lipowsky et al. 2009), motivation (Anderman et al. 2011; Levpušček and Zupančič 2008), engagement (Piwowar et al. 2013), prosocial behavior (Murray et al. 2018), perceived closeness in class (Madill et al. 2014), and attention (Murray et al. 2018).

Cognitive activation Teachers who create cognitively activating learning environments stimulate active learning and comprehension processes in their students by providing them with challenging content, tasks, and materials and by challenging them to reflect on their learning (Lipowsky et al. 2009). In order to be cognitively activating, the tasks and materials need to be within students' zone of proximal development: They should challenge but not overwhelm students (Kunter et al. 2005). Hence, cognitively activating tasks should build on students' prior knowledge, challenge previously acquired concepts, and introduce students to differing ideas or solutions (Kunter et al. 2005; Leuders and Holzäpfel 2011; Lipowsky et al. 2009). Cognitive activation has been found to be positively associated with students' mathematics achievement (Baumert et al. 2010; Levpušček and Zupančič 2008; Lipowsky et al. 2009), subject-related interest (Fauth et al. 2014; Lipowsky et al. 2009), and motivational beliefs (Levpušček and Zupančič 2008).

Supportive climate According to Klieme et al. (2009), the concept of "supportive climate" describes "observable features of teacher-learner interaction such as supportive teacher-student relationships, positive and constructive teacher feedback, a positive approach to student errors and misconceptions, individual learner support, and caring teacher behavior" (p. 141). Previous studies have shown positive associations between a supportive climate and students' subjectrelated interest (Fauth et al. 2014), social goals (Wentzel et al. 2018), social-emotional development (Rucinski et al. 2017), and achievement (Decristan et al. 2017; Decristan et al. 2016).

Monitoring as part of classroom management The concept of "classroom management" is a multicomponent construct and describes teachers' alertness for supporting students' prosocial behavior and preventing inappropriate behavior (Kounin 1970). A systematic review identifies five empirically supported domains of classroom management: (a) maximizing structure; (b) posting, teaching, reviewing, monitoring, and reinforcing expectations; (c) actively engaging; and (d) using strategies for responding to appropriate as well as to (e) inappropriate behaviors (Simonsen et al. 2008, p. 353). In previous studies, monitoring has been identified as one key 
aspect of classroom management (Göllner et al. 2018; Kunter et al. 2007; Piwowar et al. 2013; Simonsen et al. 2008). Kunter et al. (2008) define monitoring as the degree to which teachers try to prevent disruptions by being attentive to student behavior, and Kounin (1970) describes this alertness to classroom activities as "withitness." In the context of individualization, monitoring might be especially important, because effective monitoring in class refers to teachers being aware and attentive to activities and interactions of individual students in class, in order to immediately respond to behaviors of individual students and to identify adequate strategies to intervene and to support individual students. In previous studies, monitoring was positively associated with student-perceived social support (Kunter et al. 2008).

\section{Relation between individualization and teaching quality}

Some researchers have opened the discussion if or how individualization and teaching quality are related to or are dependent on each other (Klieme and Warwas 2011). While some studies include individualization in their operationalization of teaching quality (Magen-Nagar and Shachar 2017), others find that teaching quality serves as a mediator between individualization and student outcomes (Brühwiler 2014). To complicate matters, both individualization and teaching quality are multidimensional constructs. In this study, we conceptualize individualization as multidimensional and differentiate instructional behaviors related to individualization and teacher orientations related to individualization. Differential relation between the behavioral components of individualization, the respective orientations, and sub-aspects of teaching quality is hence conceivable. Since research investigating their relation is still scarce (Klieme 2018), the present study is exploratory. Our analyses were driven by the following assumptions.

Relation with cognitive activation Providing cognitively activating lessons requires of teachers, among having good content knowledge, to know their students' level of prior knowledge, interest, and motivation. This knowledge needs to be translated into individualized teaching approaches, such as providing individualized materials or tasks that challenge but do not overwhelm students during learning. Students who work on tasks that are slightly above their achievement level or zone of proximal development (Vygotsky 1978) should feel optimally challenged, and this should be translated into their subjective evaluation of cognitive activation. In similar vein, students should also feel more challenged if they receive individual feedback about their learning progress (i.e., if teachers are guided in their feedback by an individual reference norm orientation). Although the notion of whether individualized instructional practices and individual reference norm orientation actually lead to a selection of objectively more cognitively activating materials and tasks still remains open for investigation, we assume that they should lead to a higher level of perceived cognitive activation in class.

Relation with supportive climate Supportive climate refers to positive and constructive teacher feedback and individual learner support. Constructive feedback and individual learner support are inherently individualized and should translate into students' perceptions of supportive climate. Investigating how teacher individualized teaching behaviors are perceived by students, Vaughn and colleagues asked over 800 students which of two teachers they would prefer: One was characterized as "adaptive" and the other one as a "normal" or "non-adaptive" teacher. While students differed in their choices, they did perceive the "adaptive" teachers as "approachable, friendly, and able to relate to students on a personal basis" (Vaughn et al. 1993, p. 116). We therefore assume that students 
would also feel more supported if their teachers judge their performance based on past performances - and thus apply an individual reference norm orientation.

Relation with classroom management Several domains of classroom management have been identified (Simonsen et al. 2008). In the present study, we focused on monitoring, which has been associated with various positive student outcomes (Kunter et al. 2007). Monitoring is defined as teachers being attentive to student (learning) behaviors in the classroom (Kunter et al. 2008). Moreover, monitoring has also been classified as a key element of individualized teaching (cp. Beck et al. 2008; Wang 1980). Likewise, we assume that teachers who adapt and individualize materials and tasks to the level of student achievement are perceived by their students as more attentive to their students' learning progress and learning behaviors. Teachers' individualized teaching practices and an individual reference norm orientation might therefore translate into a higher student-perceived monitoring.

\section{Context variables as moderators: the offer-and-use model of learning}

Learning always takes place in a context. An established theoretical framework which describes how individual and contextual factors interact and shape individual students' learning is the offerand-use model (Fend 1981; Helmke 2003). Individual factors are students' individual cognitive, social, and motivational disposition. Proficiency in the language of instruction is also an important individual factor. Classroom composition, for example, with regard to language composition, on the other hand, is a contextual variable. In the offer-and-use model, contextual variables (e.g., language composition of the learning group) are assumed to moderate effects of teachers' professional competence (e.g., individualization strategies) and student-perceived teaching quality. These theoretical assumptions have been supported in previous empirical work.

Hochweber and colleagues (Hochweber et al. 2014), for example, found that aspects of teaching quality such as effective classroom management (including monitoring) interact with context variables such as parental educational background and academic composition of achievement in the class: In low-performing classes, students with highly educated parents outperformed students with lower educated parents when classroom management was poor. If classroom management was excellent, however, this grade advantage was reduced.

For individualization these results are not as clear. In a study on the effect of individualized instruction on student reading competencies, Groeneveld and Knigge (2015) did not find an interaction of reading competencies with disadvantageous class compositions (operationalized as a low average socioeconomic background in class).

In the context of growing sociocultural and linguistic heterogeneity in the classroom, questions have been raised whether teachers' offers (e.g., individualized teaching) and students' perceptions of these offers (e.g., the perceived teaching quality) differ depending on the linguistic composition of the classroom. The first evidence for the German context comes from a study by Klusmann et al. (2016) who showed that language-related classroom composition moderated the relation between teachers' emotional exhaustion and student achievement. In classes with a high percentage of language minority students, teachers' emotional exhaustion was more strongly negatively related to students' achievement.

However, more research is needed to understand if and how language-related classroom composition interacts with teaching quality. The present study is an exploratory first step toward this goal. We investigated (1) how teacher self-reported individualized teaching 
practices and their individual reference norm orientation are related to student-perceived teaching quality (i.e., cognitive activation, supportive climate, and monitoring), and we analyzed if the relation between teachers' self-reported individualization in class and student-perceived teaching quality varies as a function of language-related classroom composition. We expected moderation effects for each of the student-perceived instructional quality aspects. The tested relation is depicted in Fig. 1a and b.

In our study, we focused on mathematics classes. In the context of linguistic diversity, previous research has shown that mathematics teachers find it more difficult to accurately predict achievement of GSL students if teaching materials are linguistically complex (Hachfeld et al. 2010). Individualizing math instruction might therefore be more complex in linguistically heterogeneous classes. At the same time, languages competencies play an important role for the development of mathematical competences (Paetsch et al. 2015).

\section{Method}

\section{Sample}

Data from this study were drawn from a longitudinal study that examined the relation between student-perceived teachers' beliefs, teachers' instructional behaviors, and student

\section{Classroom level}

a
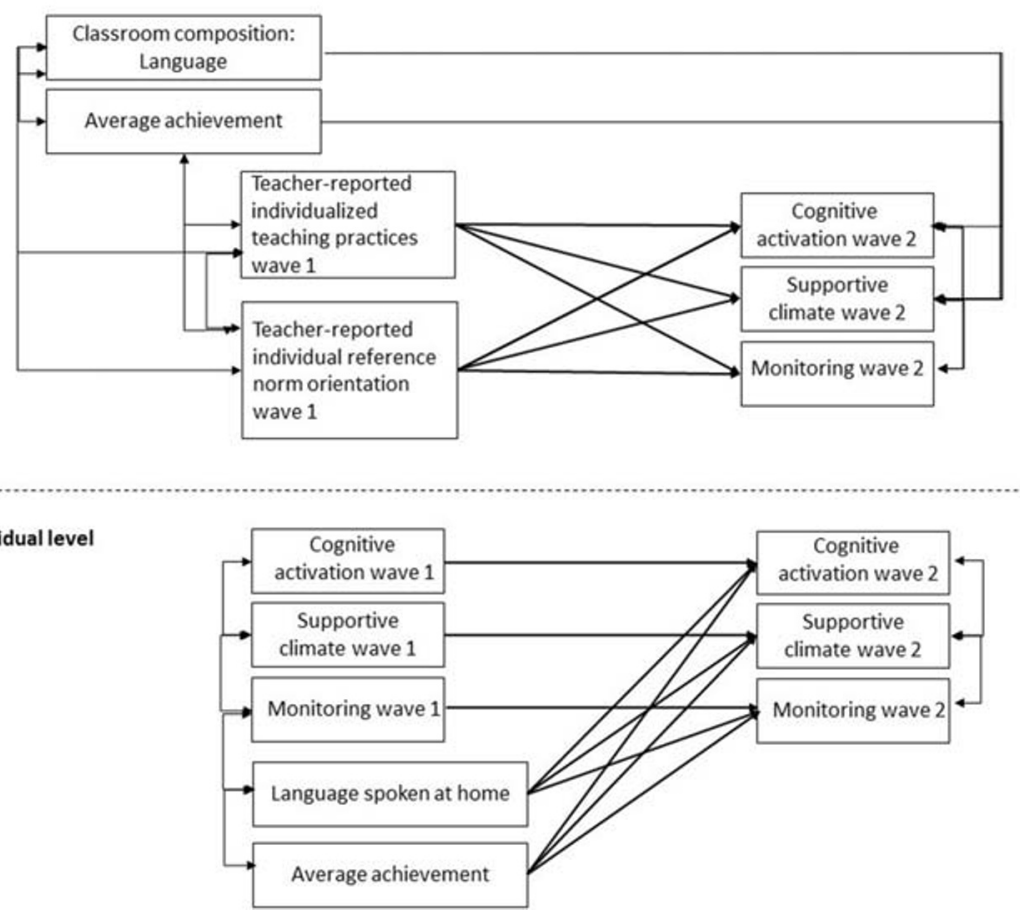

Fig. 1 a Hypothesized statistical relations in step 1 of the analyses. b Hypothesized statistical relations in step 2 of the analyses 


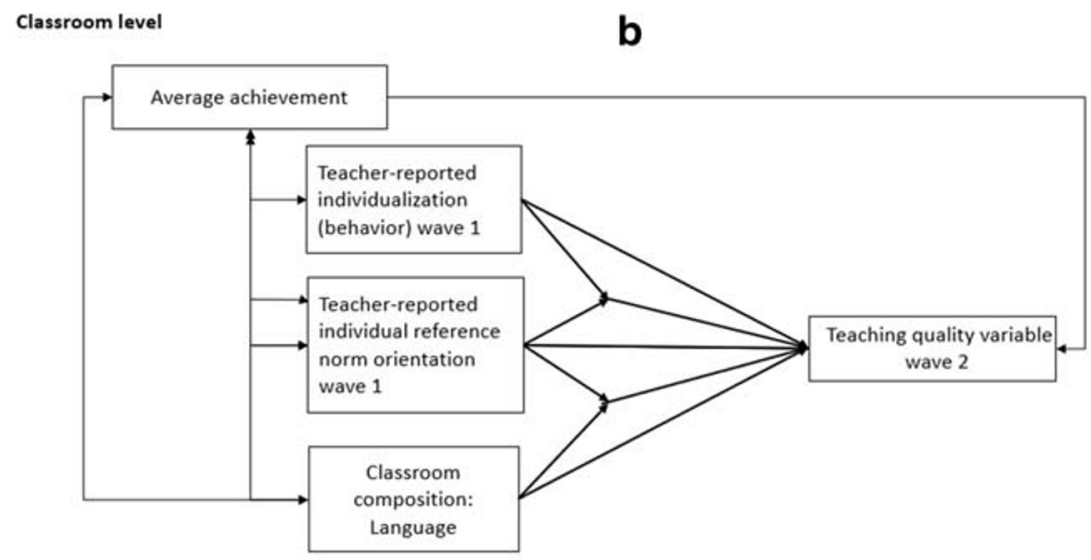

Individual level

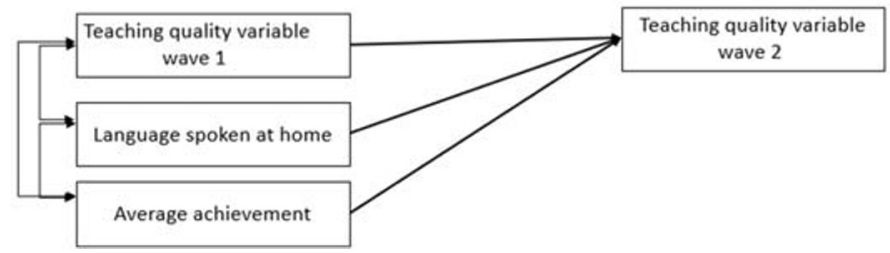

Fig. 1 (continued)

motivation (Lazarides \& Rubach, 2015-2016). This study focused on data of ninth and tenth graders that participated in the first data assessment (wave 1). Students were considered in the study if their mathematics teachers had reported data on their individualized teaching practices and individual reference norm orientation at wave 1 . A total of 490 students $(56.1 \%$ girls; age, $M=14.50$ years, $\mathrm{SD}=0.85$ ) from 32 mathematics classrooms and their respective 32 mathematics teachers ( $51.6 \%$ men; years of teaching experience, $M=20.51, \mathrm{SD}=13.77$; range, $2-$ 43) were included in this study. Approximately one-third of all students (32\%) were language minority students who reported that they were not native German speakers. Teacher and student data were assessed at the end of a compulsory class by trained research assistants. The research assistants shortly introduced the study and were able to answer questions regarding the survey. Surveys took approximately $30 \mathrm{~min}$ to complete. Half the students attended a gymnasium (the academic track in Germany; 51.20\%). The other half attended an integrated secondary school (a type of secondary school that provides courses for different ability levels; $48.8 \%$ ).

Data of wave 1 were assessed 2 months after the beginning of the school year in autumn 2015 and for wave 2 in spring 2016. Participating schools were randomly selected from the population of schools in Berlin, Germany, where the study was conducted. Parental consent was obtained for those students who were younger than 14 years (Berlin Senate Administration for Education Youth and Science 2013). Students were informed of the voluntary nature of their participation. 


\section{Measures}

Teachers' responses were included from wave 1 and students' responses were from wave 1 and 2. All answers were given on a five-point Likert-scale ranging from 1 (does not apply at all) to 5 (fully applies).

Student-perceived cognitive activation To assess student-perceived cognitive activation, we used a three-item scale from Kunter et al. (2008). An example item is "Our mathematics teacher asks us to explain our thought processes thoroughly." The reliability of the scale was good at both waves (wave $1, \alpha=.74 / \omega=.80$; wave $2, \alpha=.79 / \omega=.80$ ).

Student-perceived supportive climate Student-perceived supportive climate in mathematics classrooms was operationalized with a scale that tapped students' perceptions of teacherstudent relationship in mathematics class. The three-item scale was developed based on Kunter et al. (2002). An example item is "My mathematics teacher is interested in what I have to say." The reliability of the scale was good at both waves (wave $1, \alpha=.86 / \omega=.87$; wave $2, \alpha=.88$ / $\omega=.89)$.

Student-perceived monitoring Classroom management in mathematics classrooms was operationalized with a scale that tapped students' perceptions of monitoring in mathematics class. The three-item scale was developed based on Kunter et al. (2008). An example item is "Our mathematics teacher immediately notices if we get distracted." The reliability of the scale was good at both waves (wave $1, \alpha=.83 / \omega=.84$; wave $2, \alpha=.86 / \omega=.87$ ).

Teacher self-reported individualized teaching practices Teacher self-reported individualized teaching practices in mathematics classes was assessed with a five-item scale which was developed based on Clausen (2002). The scale taps teachers' instructional practices related to individualization in class (i.e., "I provide students who work on tasks quickly with extra tasks to challenge them."). The internal consistency of the scale was good (wave $1, \alpha=.86$, $\omega=.86)$.

Teacher self-reported individual reference norm orientation Teacher self-reported individual reference norm orientation in mathematics classes was assessed with a four-item scale which was developed based on Clausen (2002). The scale taps teachers' beliefs and orientations related to the reference norm during grading (i.e., "When talking about 'good achievement', the student has improved compared to the past."). The internal consistency of the scale was good (wave $1, \alpha=.83 ; \omega=.85$ ).

Language background Students' language background was assessed with the question which language the students had spoken at home in childhood and was coded as a dummy-coded variable $(0=$ native German speakers; $1=$ German as a second language (GSL) speakers).

Classroom composition in relation to non-native German speakers We calculated the proportion of GSL students in each classroom by aggregating the individual student level categorizations per class. This procedure has been applied in previous research (Rjosk et al. 2017) and allows to assess the linguistic heterogeneity of the classroom (i.e., proportion of students who speak German as a second language). 


\section{Statistical analyses}

We conducted multilevel regression analyses to examine the relation between teacher selfreported individualized teaching practices in class and their individual reference norm orientation with student-perceived teaching quality. In a first step, we included teacher self-reported individualized teaching practices and teacher self-reported individual reference norm orientation at wave 1 as predictors of student-perceived cognitive activation, supportive climate, and monitoring at wave 2 at the classroom level and controlled for classroom composition in relation to GSL students and achievement at wave 1. At the student level, we included stability paths of student-perceived teaching quality variables, students' achievement and language spoken at home, and modelled intercorrelations among all constructs within time. This step of the analysis is depicted in Fig. 1a. In a second step, we tested if the relations between teacher self-reported individualized teaching practices, teacher self-reported individual reference norm orientation at wave 1, and student-perceived characteristics of teaching quality (cognitive activation, supportive climate, and monitoring) at wave 2 were moderated by the proportion of GSL students in class by including interaction terms at the classroom level (Hayes 2017; O'Connell and McCoach 2008). Given the complexity of the models, we tested three moderation models: one model with two interaction effects was conducted for each of the aspects of teaching quality. For a simplified interpretation of the interaction effects, all variables were $z$ standardized prior to the analysis (Aiken et al. 1991). The proportion of GSL students in class was operationalized via standard deviations and classified as very high (+2 SD) or high (+1 $\mathrm{SD})$ and very low $(-2 \mathrm{SD})$ or low $(-1 \mathrm{SD})$, respectively. A moderate proportion was at the mean level $(M=0)$ as scales were standardized. This step of the analysis is depicted in Fig. $1 \mathrm{~b}$.

Because of the complexity of the model, we conducted doubly manifest models (Marsh et al. 2009) using TYPE = TWOLEVEL function in Mplus (see online supplement for the full script). Doubly manifest models imply that manifest variables at both levels of analysis (sample mean of all items) and manifest aggregation of scales at the classroom level were used. Student-perceived characteristics of teaching quality at wave 1 were group mean centered at the student level and grand mean centered at the classroom level (Lüdtke et al. 2009). In our study, we used data from 32 mathematics classrooms (average classroom size: 15.31). To assess the reliability of the aggregated student variables, intraclass correlations (ICC) were computed for all student variables in the model (Raudenbush and Bryk 2002). An $\mathrm{ICC}_{1}$ value greater than .05 showed that individual ratings are attributable to group membership (LeBreton and Senter 2008). Analyses showed that a relatively large amount of variance in our constructs was explained by students' membership in different classrooms. For studentperceived cognitive activation at wave 2 , results showed that $12 \%$ of the variance in students' perceptions were attributable to their membership in a specific classroom $\left(\mathrm{ICC}_{1}=0.119\right)$. Furthermore, $22 \%$ of the variance in student-perceived supportive climate $\left(\mathrm{ICC}_{1}=0.215\right)$ and $34 \%$ of the variance in student-perceived monitoring $\left(\mathrm{ICC}_{1}=0.342\right)$ were attributable to classroom membership.

The goodness of model fit of the multilevel regression models was evaluated using the following criteria (Tanaka 1993): The Yuan-Bentler scaled $\chi^{2}$, Tucker and Lewis index (TLI), comparative fit index (CFI), and root mean square of approximation (RMSEA) with the associated confidence intervals (CIs). Additionally, standardized root mean residual (SRMR) values were reported. TLI and CFI values greater than .95 (Hu and Bentler 1999), RMSEA values lower than .06, and SRMR values greater than or equal to .08 (Hu and Bentler 1999) were accepted as indicators of a good model fit. 
In this study, the percentage of missing data on the study variables ranged between 0.0 and 4.5\% (see Appendix B for exact percentages per variable). We tested whether data on our dependent variables was systematically missing using Little's MCAR test (Little 1988). Findings showed that data was not systematically missing when considering gender and student achievement in the analysis: $\chi^{2}(8)=6.86, p=.552$. Missing data was handled using full information maximum likelihood estimation (FIML) which estimates missing data based on the estimated model (Enders and Bandalos 2001; Newman 2014).

All analyses were conducted using maximum likelihood estimator with robust standard errors and chi-square (MLR) values (Muthén and Muthén 1998-2015).

The Mplus program version 8.0 was used for all analyses (Muthén and Muthén 19982015).

\section{Results}

\section{Descriptive analyses}

Means and standard deviations are reported in Table 1. The intercorrelations among the study variables are reported in Table 2. Descriptive results showed positive intercorrelations among student-perceived characteristics of teaching quality at the classroom level which can be interpreted also in terms of criterion validity of these scales as they were distinct but positively interrelated. As in previous studies (Clausen 2002), teacher self-reported individualized teaching practices and individual reference norm orientation did not significantly relate to students' average achievement. However, teacher self-reported individualized teaching practices and individual reference norm orientation positively related to student-perceived monitoring at wave 2 (at the $p<.10$ level with individual reference norm orientation). The proportion of GSL students was not significantly correlated with any of the studentperceived or teacher-reported variables.

\section{Teacher self-reported individualization and student-perceived teaching quality}

The model included teacher self-reported individualized teaching practices and individual reference norm orientation as well as students' average achievement and proportion of GLS in class as predictors of class-level student-reported cognitive activation, supportive climate and monitoring at the classroom level. At the student level, we included student-reported cognitive activation, supportive climate and monitoring, and their stability paths as well as

Table 1 Descriptive statistics for the study variables

\begin{tabular}{lllll}
\hline Student-reported variables & $M_{\text {Level1 }}$ & $S D_{\text {Level 1 }}$ & $M_{\text {Level 2 }}$ & $S D_{\text {Level2 }}$ \\
\hline Cognitive activation wave 2 & 3.59 & 0.88 & 3.59 & 0.20 \\
Classroom management wave 2 & 3.60 & 0.99 & 3.67 & 0.44 \\
Supportive climate wave 2 & 3.83 & 1.00 & 3.84 & 0.33 \\
Teacher-reported variables & & & 2.74 & 0.62 \\
Individualized teaching practices time 1 & & & 3.34 & 0.79 \\
Individual reference norm orientation time 1 & & & & \\
\hline
\end{tabular}

$M$ mean, $S D$ standard deviation 
Table 2 Intercorrelations between student and teacher variables at the classroom level

\begin{tabular}{llllrrr}
\hline \multicolumn{1}{c}{2} & 3 & 4 & 5 & 6 & 7 \\
\hline 1) Classroom composition: average achievement & $-.36^{* *}$ & $.34^{\mathrm{c}}$ & -.04 & -.18 & -.22 & -.04 \\
2) Classroom composition: language & & .06 & .04 & .06 & .09 & .21 \\
3) Student-perceived cognitive activation wave 2 & & $.75^{* * *}$ & $.63^{* * *}$ & .12 & .12 \\
4) Student-perceived supportive climate wave 2 & & & $.65^{* * *}$ & .20 & .18 \\
5) Student-perceived monitoring wave 2 & & & & $.63^{* * *}$ & $.47^{*}$ \\
6) Teacher: individualized teaching practices & & & & .12 \\
7) Teacher: individual reference norm orientation & & & & \\
\hline
\end{tabular}

${ }^{\mathrm{c}} p<.10, * p<.05, * * p<.010,{ }^{* * *} p<.001$

student-reported achievement and language spoken at home. The model is depicted in Fig. 1a. Model fit indices indicated a good fit of the tested model to the empirical data $(\chi 2(5, N=$ $\left.490)=8.66, \mathrm{CFI}=0.99, \mathrm{TLI}=0.96, \mathrm{RMSEA}=0.03, \mathrm{SRMR}_{\mathrm{within}}=.03, \mathrm{SRMR}_{\text {between }}=.01\right)$.

Teacher self-reported individualized teaching practices $(\beta=.58, \mathrm{SE}=0.11, p<.001)$ and teacher self-reported individual reference norm orientation $(\beta=.36, \mathrm{SE}=0.14, p=.008)$ at wave 1 both significantly and positively correlated with student-perceived monitoring at wave 2 but not with student-perceived cognitive activation or supportive climate at wave 2 . The average level of student achievement in class at wave 1 was significantly and positively related to student-perceived cognitive activation at wave $2(\beta=.46, \mathrm{SE}=.19, p=.014)$; thus, students reported that they felt cognitively challenged especially in those classrooms that had on average a high achievement. Student-perceived monitoring at wave 2 significantly and positively correlated with student-perceived cognitive activation $(r=.87, \mathrm{SE}=.10, p<.001)$ and with student-perceived supportive climate both at wave $2(r=.74, \mathrm{SE}=.09, p<.001)$. Student-perceived cognitive activation at wave 2 significantly and positively correlated with student-perceived supportive climate at wave $2(r=.82, \mathrm{SE}=.14, p<.001)$. Teacher selfreported individualized teaching practices were not significantly correlated with teacher selfreported individual reference norm orientation $(r=.12, \mathrm{SE}=.27, p=.65)$. The proportion of GLS students in class did not significantly relate to student-reported teaching quality or teacher self-reported individualized teaching practices and individual reference norm orientation but significantly and negatively correlated with the average achievement in class $(r=-.36, \mathrm{SE}=$ $.13, p=.01)$. The model explained a substantial amount of variance in monitoring at wave 2 at the classroom level $\left(R^{2}=.58, p<.001\right)$. The coefficients are reported in Table 3 and depicted in Fig. 2. As a robustness test, we reanalyzed our data with school type as additional control variable at the classroom level because in this study, additional analyses showed that students in academic track schools perceived lower monitoring than students in non-academic track schools at waves 1 and 2 (academic track, $M=3.05, \mathrm{SD}=1.18$; non-academic track, $M=3.50$, $\mathrm{SD}=0.93 ; t(482)=-4.58, p<.001)$. However, besides the effect of average achievement on student-perceived cognitive activation becoming non-significant in the revised model, model paths did not substantially change in their strengths or significance when including the additional control variable, and it was therefore no longer considered in the further modelling process. Results of this step are reported in Appendix C. As a last step, we included studentperceived characteristics of teaching quality at wave 1 in our analyses at the classroom level which allows to test whether teacher-reported individualized teaching practices and individual reference norm orientation not only relate to student-perceived teaching quality at wave 2 but also relate to changes in student-perceived teaching quality from the beginning to the middle of the school year. Our findings showed that the relation between teacher-reported individual 
Table 3 Relation between teacher-reported instructional behaviors related to individualized teaching practices, individual reference norm orientation wave 1 and student-perceived teaching quality at wave 2

\begin{tabular}{|c|c|c|c|c|c|c|c|c|c|}
\hline & \multicolumn{3}{|c|}{$\begin{array}{l}\text { Student-perceived } \\
\text { cognitive activation }\end{array}$} & \multicolumn{3}{|c|}{$\begin{array}{l}\text { Student-perceived } \\
\text { supportive climate }\end{array}$} & \multicolumn{3}{|c|}{$\begin{array}{l}\text { Student-perceived } \\
\text { monitoring }\end{array}$} \\
\hline & $\beta$ & $\mathrm{SE}$ & $p$ & $\beta$ & $\mathrm{SE}$ & $p$ & $\beta$ & SE & $p$ \\
\hline Average Achievement & .46 & .19 & .01 & -.09 & .19 & .64 & .04 & .12 & .73 \\
\hline Language composition & .28 & .26 & .28 & .03 & .18 & .88 & .17 & .15 & .16 \\
\hline Teacher orientation $(\mathrm{T})$ & .08 & .19 & 69 & .17 & .15 & .27 & .36 & .14 & .01 \\
\hline Individualized practices $(\mathrm{T})$ & .18 & .21 & .38 & .18 & .23 & .44 & .58 & .11 & $<.001$ \\
\hline
\end{tabular}

Bold entries indicate values lower than .05 in ' $p$ ' columns

$* p<.05, * * p<.010, * * * p<.001$. $T$ teacher self-reported. Teacher orientation $=$ individual reference norm orientation of the teacher

reference norm orientation at wave 1 and student-reported monitoring at wave 2 became nonsignificant when entering monitoring at wave 1 which was due to the high stability of the construct at the classroom level. Results of this step are also reported in Appendix C.

\section{Moderation analyses}

We tested if the relations between teacher self-reported individualized teaching practices and teacher self-reported individual reference norm orientation at wave 1 and student-perceived

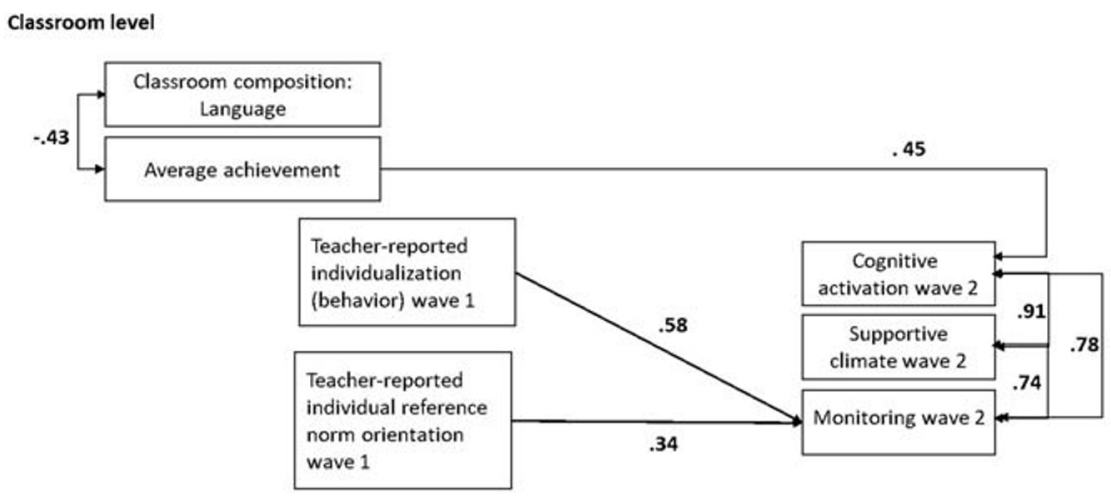

\section{Individual level}

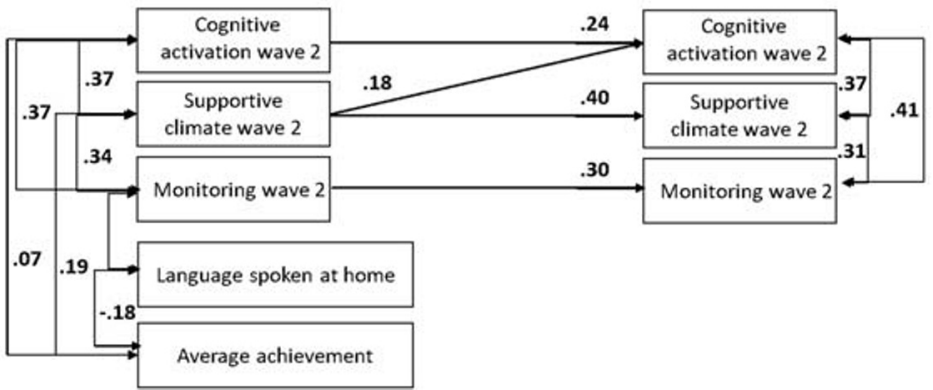

Fig. 2 Empirical relation among teacher-reported individualization and student-perceived teaching quality 
characteristics of teaching quality at wave 2 were moderated by the proportion of GSL students in class. We tested three different models by testing one model with two interaction effects for each of the aspects of teaching quality.

We did not find any significant interactions for teacher self-reported individualized teaching practices at wave 1 and any of the three student-perceived aspects of teaching quality at wave 2. For teacher self-reported individual reference norm orientation at wave 1, the relation with student-perceived cognitive activation at wave 2 was moderated by the proportion of GSL students in class $\left(\beta_{\mathrm{mod}}=.12, \mathrm{SE}=0.04, p=.002\right)$ : In classrooms with a low $(-1 S D)$ proportion of GSL students, the relation between teacher self-reported individual reference norm orientation and student-perceived cognitive activation was not significant $(\beta=-.10, \mathrm{SE}=.06$, $p=.10)$; the same applied to classrooms with a moderate proportion of GSL students in class $(M=0.00 ; \beta=.02, \mathrm{SE}=.04, p=.66)$. In classrooms with a high $(+1 \mathrm{SD})$ proportion of GSL students, the relation was positive and significant $(\beta=.14, \mathrm{SE}=.06, p=.02)$ indicating that students in classrooms with a high heterogeneity felt particularly cognitively challenged by teachers who reported to prefer an individual reference norm orientation. The interaction is plotted in Fig. 3, and conditional effects are reported in Table 4.

\section{Discussion}

While in many countries individualization is understood as best practice in teaching diverse student groups, Germany has traditionally focused on tracking students into different schools. However, societal changes in Germany in school and student composition have underlined the importance to implement methods of individualization. This has sparked national research endeavors investigating the effects of individualization and interactions with classroom composition (cp. Dumont 2019). In the context of a persistent achievement gap between students

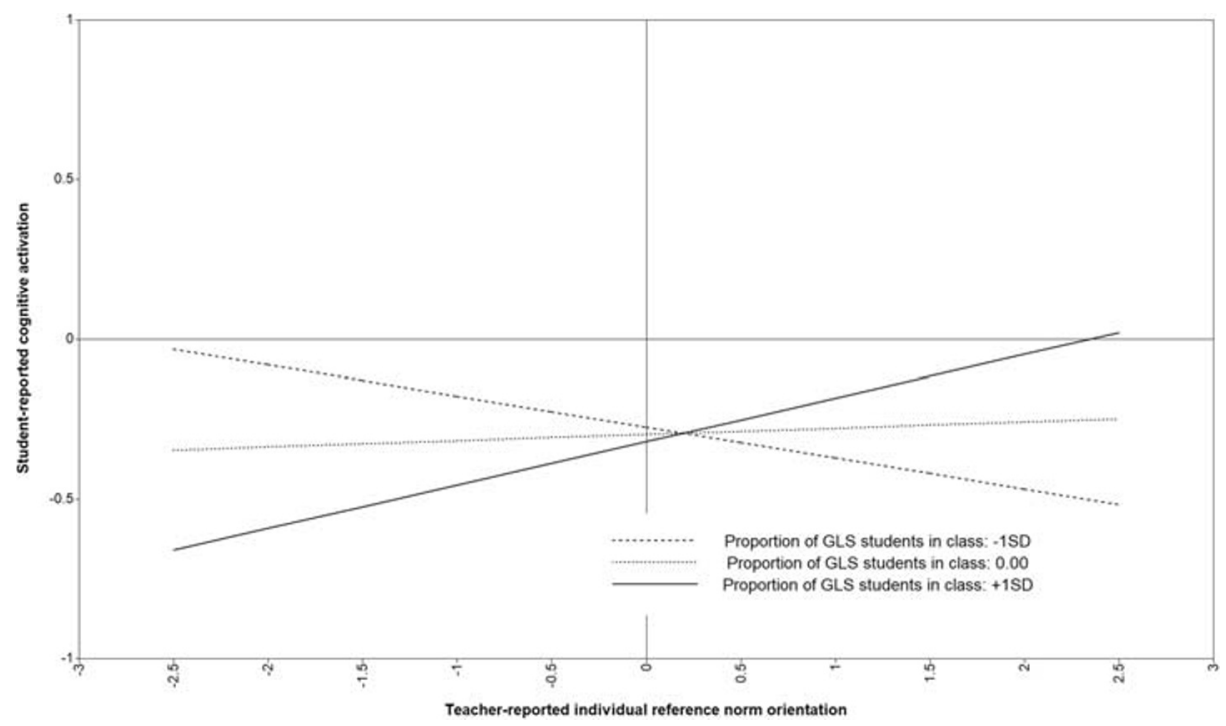

Fig. 3 Interaction between teacher-reported individual reference norm orientation at wave 1 and studentperceived cognitive activation at wave 2 by proportion of students with German as a second language (ranging from $+1 \mathrm{SD}$ to $-1 \mathrm{SD})$ 
Table 4 Conditional direct effects for the relation between teacher self-reported individual reference norm orientation wave 1 and student-perceived cognitive activation wave 2

\begin{tabular}{|c|c|c|c|c|}
\hline Classroom composition: language & Direct effect & $S E$ & $p$ & $95 \% \mathrm{CI}$ \\
\hline$-1 \mathrm{SD}$ & -0.10 & 0.06 & 0.10 & {$\left[\begin{array}{ll}-0.21 & 0.02\end{array}\right]$} \\
\hline Mean & 0.02 & 0.04 & 0.44 & {$\left[\begin{array}{ll}-0.07 & 0.11\end{array}\right]$} \\
\hline + $1 \mathrm{SD}$ & 0.14 & 0.06 & 0.02 & {$\left[\begin{array}{ll}0.03 & 0.25\end{array}\right]$} \\
\hline
\end{tabular}

of native and non-native German language (OECD 2015), the relation of individualization with basic aspects of teaching quality and with classroom composition has been discussed. The present, exploratory study aims to add to the growing literature on these processes. Precisely, we investigated how teacher self-reported individualized teaching practices and self-reported individual reference norm orientation are related to student-perceived teaching quality (i.e., cognitive activation, supportive climate, and monitoring) and if their relation is moderated by the proportion of GSL students in class.

Our findings show that teacher self-reported individualized teaching practices and their individual reference norm orientation are substantially related to student-perceived monitoring. Hence, teachers who apply individualized teaching practices in class (i.e., providing different tasks and materials to their students depending on students' ability level) and who consider each students' individual achievement level when giving feedback to their students are perceived by their students as attentive to students' learning progress. This finding underlines research suggesting that monitoring is a key element of individualized and adaptive teaching (Beck et al. 2008; Wang 1980). It also supports the assumption that individualization influences student learning by affecting aspects of teaching quality (cp. Vogt and Brühwiler 2014).

We did not, however, find significant relation between teacher self-reported individualized teaching practices and their individual reference norm orientation and studentperceived cognitive activation or supportive climate. Why we did not find any effects here is open to discussion. The lack of findings for supportive climate might have methodological reasons: In our operationalization of the teacher-reported constructs, we focused on individualization and feedback based on (prior) achievement. We did not assess individualized support regarding other forms of social or emotional support. Supportive climate as perceived by the students was assessed via items such as "Most teachers are interested in what I have to say" or "For most of my teachers it is important that I feel comfortable." Help in the academic domain might not necessarily transfer to perceive support in other domains. Moreover, other moderators than the ones assessed in our study might be relevant for the perception of social support. One study that included "feelings of alienation" showed that students, especially those who felt alienated in school, perceived the "adaptive teacher" who individualized her teaching practices to the needs of the students, as "more approachable and friendly toward the students" (Vaughn et al. 1993, p. 116).

While we did not find a main effect for cognitive activation, our results showed that for the relation between teacher self-reported individual reference norm orientation and studentperceived cognitive activation, the proportion of GSL students in class served as a moderator. In classes with high proportions of GSL students, students reported higher cognitive activation when teachers reported to apply individual reference norm orientation. One possible explanation for our finding could be that in diverse classrooms, students differ more strongly in terms of language skills and understanding of tasks and materials and thus might face greater 
challenges than students in homogeneous classrooms (cp. Hachfeld et al. 2010). Focusing on students' personal learning progress as opposed to students' achievement relative to that of their peers might be even more important in such heterogeneous contexts. This finding adds to the literature showing that individualized teaching strategies can contribute to greater learning gains in heterogeneous classes (Beck et al. 2008) and that immigrant students benefit even more from better classroom management and social support than their non-immigrant peers (Seiz et al. 2016). Future studies should look deeper into the mechanisms driving their relation.

Overall, an important message to teachers that follows from our findings is that the effects of their instructional approaches in class on students' perceptions of the quality of instruction can be context-specific. Our findings suggest that teachers who apply individualized teaching practices in class might enhance students' feelings of being cognitively challenged if they are in diverse classrooms. Thus, this method of instruction seems especially promising in such heterogeneous settings. Regarding teacher education, our findings highlight that methods of instruction should always be discussed in regard to the classroom context as they can have differential effects on students' perceptions of the classroom depending on contextual factors. The question that needs to be addressed is which teaching methods are effective in which learning context. Our findings are a first exploratory step to answer this question as they show that teachers who aim to raise the level of cognitive activation in class should apply individualized teaching practices especially when teaching in heterogeneous classrooms. These implications, however, have to be evaluated against the limitations of our study.

\section{Limitations}

Several limitations of the current study arise from the restricted assessment of individualization. First, our scales assessing teacher self-reported individualized teaching practices and individual reference norm orientation mainly focused on performance-related differences. In the context of sociocultural and linguistic diversity, a more differentiated approach could be fruitful. An important question thus is whether teachers are willing to consider sociocultural and linguistic differences in their teaching and whether they are aware of linguistic challenges of non-native German students when selecting tasks (cp. Hachfeld et al. 2010) and providing individual support and feedback. Previous research shows that while teachers use curriculumrelated actions of meeting the individual needs of the students rather frequently, culturalrelated actions are only rarely used (Anderson et al. 2012). In this context, professional competences like teachers' beliefs should also be considered. Hachfeld et al. (2015), for example, found a positive association between beginning teachers' multicultural beliefs and their willingness to adapt their teaching in terms of students' cultural diversity.

Second, we assessed teachers' individualized teaching practices and their individual reference norm orientation using self-reported data rather than using classroom observational data. Teachers might be biased in their responses due to socially desirable response behaviors. Their responses might also be biased because teachers may not be able to accurately evaluate their own classroom behaviors in regard to individualization or might overestimate their abilities and report biased information about their own teaching behaviors. Future studies should address this limitation by using multiple sources of data on teaching behaviors, especially observational data. A strength of our study in this context is, however, that we were able to bring together different perspectives by incorporating teachers' and students' evaluations. The 
question of what students actually perceive when teachers make adaptations should be further investigated in future studies (Vaughn et al. 1993).

Third, we only examined the hypothesized relation with regard to student-perceived mathematics instruction. We focused on the domain of mathematics because, especially in mathematics, students' motivation declines during secondary school (Jacobs et al. 2002). Identifying teaching behaviors that lead to high perceived teaching quality in this school subject might not only be a way to increase students' motivation but also allows to plan instructional settings more effectively in this domain which is often perceived by students as "boring," "difficult," and "not well taught" (Murray 2011).

Fourth, participation rate of contacted schools in this study was low, and we had to include those schools in our sample that agreed to participate. Other studies are needed to test the relations shown in this study in greater and more representative samples. However, participating schools were representative in terms of school types existing in the targeted population of schools.

\section{Implications and Conclusions}

The main contribution of our exploratory study to the current research is to add to our knowledge about how students perceive teachers' efforts to individualize their instruction. In our study, teacher individualization was not related to student-perceived cognitive activation and social support - two important aspects of teaching quality. However, students did rate classroom management higher when teachers reported to individualize. Classroom management, in turn, has been identified as predictor of students' achievement in primary school (Fauth et al. 2014), whereas cognitive activation and social support were only related to subject-related interest.

Going beyond these findings, our results also contribute to the growing body of evidence that classroom composition can differentially impact the relation between teachers' behaviors and students' outcomes (e.g., perception of teaching quality, performance) (Decristan et al. 2017; Koth et al. 2008; Pas et al. 2015; Rjosk et al. 2014). Taken together, these results have implications for teacher training and professional development: Future teachers need to be made aware of the potential context specificity of their behaviors. Different forms and aspects of individualization are important aspects to be addressed in teacher education not only with regard to students' achievements but also referring to students' interests, pre-knowledge, and motivation. The specific contribution of our exploratory study thereby is to highlight that the classroom context can interact with processes of individualized teaching in secondary classrooms.

Acknowledgements This research is funded by the Deutsche Forschungsgemeinschaft (DFG, German Research Foundation) under Germany's Excellence Strategy - EXC 2002/1 'Science of Intelligence' - project number 390523135 and by DFG under project number LA 3522/5-1.

Funding Open Access funding enabled and organized by Projekt DEAL.

Open Access This article is licensed under a Creative Commons Attribution 4.0 International License, which permits use, sharing, adaptation, distribution and reproduction in any medium or format, as long as you give appropriate credit to the original author(s) and the source, provide a link to the Creative Commons licence, and indicate if changes were made. The images or other third party material in this article are included in the article's Creative Commons licence, unless indicated otherwise in a credit line to the material. If material is not included in the article's Creative Commons licence and your intended use is not permitted by statutory regulation or exceeds the permitted use, you will need to obtain permission directly from the copyright holder. To view a copy of this licence, visit http://creativecommons.org/licenses/by/4.0/. 


\section{References}

Aiken, L. S., West, S. G., \& Reno, R. R. (1991). Multiple regression: Testing and interpreting interactions. Thousand Oaks, CA: Sage.

Algozzine, B., \& Anderson, K. M. (2007). Tips for teaching: Differentiating instruction to include all students. Preventing school failure: Alternative education for children and youth, 51(3), 49-54. https://doi. org/10.3200/PSFL.51.3.49-54.

Anderman, L. H., Andrzejewski, C. E., \& Allen, J. (2011). How do teachers support students' motivation and learning in their classrooms? Teachers College Record, 113(5), 969-1003.

Anderson, D. L., Lubig, J., \& Smith, M. (2012). Meeting the needs of all students: How student teachers identify individualization. Education Research and Perspectives (Online), 39, 1-23.

Autorengruppe Bildungsberichterstattung (2018). Bildung in Deutschland 2018. Ein indikatorengestützter Bericht mit einer Analyse zu Wirkungen und Erträgen von Bildung [Education in Germany. An indicatorbased report including an analysis of educational gains]. Bielefeld: W. Bertelsmann Verlag

Autorengruppe Bildungsberichterstattung (2016). Bildung in Deutschland 2018. Ein indikatorengestützter Bericht mit einer Analyse zu Bildung und Migration [Education in Germany. An indicator-based report including an analysis of education and migration]. Bielefeld: W. Bertelsmann Verlag.

Baumert, J., Maaz, K., Neumann, M., Becker, M., \& Dumont, H. (2017). Die Berliner Schulstrukturreform: Hintergründe, Zielstellungen und theoretischer Rahmen [The educational reform in Berlin: Aims and theoretical considerations]. In M. Neumann, M. Becker, J. Baumert, K. Maaz, \& Köller, O. (Eds.). Zweigliedrigkeit im deutschen Schulsystem. Potenziale und Herausforderungen in Berlin. Münster: Waxmann.

Baumert, J., Kunter, M., Blum, W., Brunner, M., Voss, T., Jordan, A., et al. (2010). Teachers' mathematical knowledge, cognitive activation in the classroom, and student progress. American Educational Research Journal, 47(1), 133-180. https://doi.org/10.3102/0002831209345157.

Beck, E., Baer, M., Guldimann, T., Bischoff, S., Brühwiler, C., \& Müller, P. (2008). Adaptive Lehrkompetenz: Analyse und Struktur, Veränderung und Wirkung handlungssteuernden Lehrerwissens [Adaptive teaching competency. Analysis and structure, variability and effects of teacher knowledge on teachers' actions]. Münster, Germany: Waxmann.

Berlin Senate Administration for Education Youth and Science. (2013). Verfahren zur Genehmigung empirischer Studien an Berliner Schulen [Permission procedure for empirical studies in schools in Berlin]. Retrieved from http://www.ewi-psy.fu-berlin.de/service/Genehmigung_empirischer_Untersuchungen_in_Berliner_ Schulen_April_2013.pdf

Brühwiler, C. (2014). Adaptive Lehrkompetenz und schulisches Lernen: Effekte handlungssteuernder Kognitionen von Lehrpersonen auf Unterrichtsprozesse und Lernergebnisse der Schülerinnen und Schüler [Adaptive teaching skills and academic learning. Effects of action-controlling cognitions of teachers on the teaching processes and learning outcomes of the students]. Münster, Germany: Waxmann.

Brüning, L., \& Saum, T. (2010). Individualisierung und Differenzierung - aber wie? Kooperatives Lernen erschließt neue Zugänge [Individualization and differentiation: Using cooperative learning]. Pädagogik, 62, $12-15$.

Clausen, M. (2002). Unterrichtsqualität: Eine Frage der Perspektive? [Teaching quality: A question of perspective?]. Münster, Germany: Waxmann.

Connor, C. M. (2017). Using technology and assessment to personalize instruction: preventing reading problems. Prevention Science, 20,1-11. https://doi.org/10.1007/s11121-017-0842-9.

Corno, L., \& Snow, R. E. (1986). Adapting teaching to individual differences among learners. In M. C. Wittrock (Ed.), Handbook of research in teaching (pp. 605-629). London: MacMillan.

Decristan, J., Fauth, B., Kunter, M., Büttner, G., \& Klieme, E. (2017). The interplay between class heterogeneity and teaching quality in primary school. International Journal of Educational Research, 86, 109-121. https://doi.org/10.1016/j.ijer.2017.09.004.

Decristan, J., Kunter, M., Fauth, B., Büttner, G., Hardy, I., \& Hertel, S. (2016). What role does teaching quality play for elementary school children's science competence? A focus on students at risk. Journal for Educational Research Online/Journal für Bildungsforschung Online, 8(1), 66-89.

Dee, A. L. (2010). Preservice teacher application of differentiated instruction. The Teacher Educator, 46(1), 53-70.

Dräger, J. (2009). Individuelle Förderung für ein faires und leistungsstarkes Schulsystem [Individual support for a fair and high-performing school system]. In B. Stiftung (Ed.), Heterogenität und Bildung: Individuelle Förderung in Deutschland - Hindernisse und Herausforderungen (pp. 4-8). Gütersloh, Germany: Bertelsmann Stiftung.

Dumont, H. (2019). Neuer Schlauch für alten Wein? Eine konzeptuelle Betrachtung von individueller Förderung im Unterricht [Adaptive teaching: Conceptual reflections]. Zeitschrift für Erziehungswissenschaft, 22, 249277. https://doi.org/10.1007/s11618-018-0840-0. 
Enders, C. K., \& Bandalos, D. L. (2001). The relative performance of full information maximum likelihood estimation for missing data in structural equation models. Structural Equation Modeling, 8(3), 430-457.

Fauth, B., Decristan, J., Rieser, S., Klieme, E., \& Büttner, G. (2014). Student ratings of teaching quality in primary school: Dimensions and prediction of student outcomes. Learning and Instruction, 29, 1-9. https://doi.org/10.1016/j.learninstruc.2013.07.001.

Federal Ministry of Labour and Social Affairs (2011). Short Version of the National Action Plan to implement the UN Convention on the Rights of Persons with Disabilities. Goals and contents of the National Action Plan. Retrieved from https://www.bmas.de/SharedDocs/Downloads/DE/PDF-Publikationen/a740-short-en.pdf;jsessionid = FADAFEBC65F678C849505568ED54634E?_blob = publicationFile\&v = 3 [2019/07/15].

Fend, H. (1981). Theorie der Schule. 2., durchgesehene Auflage [Theory of the school, second revised edition]. München, Germany: Urban \& Schwarzenberg.

Göllner, R., Wagner, W., Eccles, J. S., \& Trautwein, U. (2018). Students' idiosyncratic perceptions of teaching quality in mathematics: A result of rater tendency alone or an expression of dyadic effects between students and teachers? Journal of Educational Psychology, 110(5), 709-725. https://doi.org/10.1037/edu0000236.

Groeneveld, I., \& Knigge, M. (2015). Moderation primärer sozialer Disparitäten im Leseverständnis in Abhängigkeit vom wahrgenommenen Verhalten der Lehrkraft und der Klassenzusammensetzung [Moderation of social disparities in reading achievement through classroom factors]. Zeitschrift für Bildungsforschung, 5(1), 51-72. https://doi.org/10.1007/s35834-014-0115-7.

Hachfeld, A., Anders, Y., Schroeder, S., Stanat, P., \& Kunter, M. (2010). Does immigration background matter? How teachers' predictions of students' performance relate to student background. International Journal of Educational Research, 49, 78-91. https://doi.org/10.1016/j.ijer.2010.09.002.

Hachfeld, A., Hahn, A., Schroeder, S., Anders, Y., \& Kunter, M. (2015). Should teachers be colorblind? How multicultural and egalitarian beliefs differentially relate to aspects of teachers' professional competence for teaching in diverse classrooms. Teaching and Teacher Education, 48, 44-55. https://doi.org/10.1016/j. tate.2015.02.001.

Hattie, J. (2009). Visible learning. A synthesis of over 800 meta-analyses relating to achievement. London: Routledge.

Hayes, A. F. (2017). Introduction to mediation, moderation, and conditional process analysis: A regressionbased approach. New York, NY: Guilford Press.

Helmke, A. (2003). Unterrichtsqualität. Erfassen, Bewerten, Verbessern [Capturing, Evaluating, and Improving Teaching Quality]. Seelze, Germany: Kallmeyer.

Hochweber, J., Hosenfeld, I., \& Klieme, E. (2014). Classroom composition, classroom management, and the relationship between student attributes and grades. Journal of Educational Psychology, 106(1), 289-300. https://doi.org/10.1037/a0033829.

Hu, L.-T., \& Bentler, P. M. (1999). Cutoff criteria for fit indexes in covariance structure analysis: Conventional criteria versus new alternatives. Structured Equation Modeling, 6(1), 1-55. https://doi.org/10.1080 $/ 10705519909540118$.

Jacobs, J. E., Lanza, S., Osgood, D. W., Eccles, J. S., \& Wigfield, A. (2002). Changes in children's selfcompetence and values: Gender and domain differences across grades one through twelve. Child Development, 73(2), 509-527. https://doi.org/10.1111/1467-8624.00421.

Klieme, E. (2018). Unterrichtsqualität [Teaching quality]. In M. Gläser-Zikuda, M. Harring, \& C. Rohlfs (Eds.), Handbuch Schulpädagogik [Handbook of school pedagogy]. (pp. 393-408) Münster, Germany: Waxmann.

Klieme, E., Pauli, C., \& Reusser, K. (2009). The Pythagoras study: Investigating effects of teaching and learning in Swiss and German mathematics classrooms. In T. Janík \& T. Seidel (Eds.), The power of video studies in investigating teaching and learning in the classroom (pp. 137-160). Münster: Waxmann.

Klieme, E. \& Warwas, J. (2011). Konzepte der individuellen Förderung. [Concepts of individual fostering]. Zeitschrift für Pädagogik, 57(6), 805-818. URN: urn:nbn:de:0111-opus-87822

Klusmann, U., Richter, D., \& Lüdtke, O. (2016). Teachers' emotional exhaustion is negatively related to students' achievement: Evidence from a large-scale assessment study. Journal of Educational Psychology, 108(8), 1193-1203. https://doi.org/10.1037/edu0000125.

Koth, C. W., Bradshaw, C. P., \& Leaf, P. J. (2008). A multilevel study of predictors of student perceptions of school climate: The effect of classroom-level factors. Journal of Educational Psychology, 100(1), 96-104. https://doi.org/10.1037/0022-0663.100.1.96.

Kounin, J. S. (1970). Discipline and group management in classrooms. Oxford, England: Holt, Rinehart \& Winston.

Kunter, M., Baumert, J., \& Köller, O. (2007). Effective classroom management and the development of subjectrelated interest. Learning and Instruction, 17(5), 494-509. https://doi.org/10.1016/j. learninstruc.2007.09.002.

Kunter, M., Brunner, M., Baumert, J., Klusmann, U., Krauss, S., Blum, W., et al. (2005). Der Mathematikunterricht der PISA-Schülerinnen und -Schüler. Schulformunterschiede in der 
Unterrichtsqualität [Quality of mathematics instruction across school types: Findings from PISA 2003]. Zeitschrift für Erziehungswissenschaft, 8(4), 502-520. https://doi.org/10.1007/s11618-005-0156-8.

Kunter, M., Klusmann, U., Baumert, J., Richter, D., Voss, T., \& Hachfeld, A. (2013). Professional competence of teachers: Effects on instructional quality and student development. Journal of Educational Psychology, 105(3), 805.

Kunter, M., Schümer, G., Artelt, C., Baumert, J., Klieme, E., Neubrand, M., et al. (2002). PISA 2000: Dokumentation der Erhebungsinstrumente [PISA 2000: Documentation of scales]. Berlin, Germany: Max-Planck-Institut für Bildungsforschung.

Kunter, M., Tsai, Y.-M., Klusmann, U., Brunner, M., Krauss, S., \& Baumert, J. (2008). Students' and mathematics teachers' perceptions of teacher enthusiasm and instruction. Learning and Instruction, 18(5), 468-482. https://doi.org/10.1016/j.learninstruc.2008.06.008.

LeBreton, J. M., \& Senter, J. L. (2008). Answers to 20 questions about interrater reliability and interrater agreement. Organizational Research Methods, 11(4), 815-852. https://doi.org/10.1177/1094428106296642.

Leuders, T., \& Holzäpfel, L. (2011). Kognitive Aktivierung im Mathematikunterricht [Cognitive activation in mathematics instruction]. Unterrichtswissenschaft, 39(3), 213-230.

Levpušček, M. P., \& Zupančič, M. (2008). Math achievement in early adolescence: The role of parental involvement, teachers' behavior, and students' motivational beliefs about math. The Journal of Early Adolescence, 29(4), 541-570. https://doi.org/10.1177/0272431608324189.

Lipowsky, F., Rakoczy, K., Pauli, C., Drollinger-Vetter, B., Klieme, E., \& Reusser, K. (2009). Quality of geometry instruction and its short-term impact on students' understanding of the Pythagorean Theorem. Learning and Instruction, 19(6), 527-537. https://doi.org/10.1016/j.learninstruc.2008.11.001.

Little, R. J. (1988). A test of missing completely at random for multivariate data with missing values. Journal of the American Statistical Association, 83(404), 1198-1202.

Lüdtke, O., Robitzsch, A., Trautwein, U., \& Kunter, M. (2009). Assessing the impact of learning environments: How to use student ratings of classroom or school characteristics in multilevel modeling. Contemporary Educational Psychology, 34(2), 120-131. https://doi.org/10.1016/j.cedpsych.2008.12.001.

Madill, R. A., Gest, S. D., \& Rodkin, P. C. (2014). Students' perceptions of relatedness in the classroom: The roles of emotionally supportive teacher-child interactions, children's aggressive-disruptive behaviors, and peer social preference. School Psychology Review, 43(1), 86-105.

Magen-Nagar, N., \& Shachar, H. (2017). Quality of teaching and dropout risk: A multi-level analysis. Journal of Education for Students Placed at Risk, 22(1), 9-24. https://doi.org/10.1080/10824669.2016.1242069.

Marsh, H. W., Lüdtke, O., Robitzsch, A., Trautwein, U., Asparouhov, T., Muthén, B., \& Nagengast, B. (2009). Doubly-latent models of school contextual effects: Integrating multilevel and structural equation approaches to control measurement and sampling error. Multivariate Behavioral Research, 44(6), 764-802. https://doi. org/10.1080/00273170903333665.

Martschinke, S. (2015). Facetten adaptiven Unterrichts aus der Sicht der Unterrichtsforschung [Aspects of adaptive teaching from a perspective of instructional research]. In K. Liebers, B. Landwehr, A. Marquardt, \& K. Schlotter (Eds.), Lernprozessbegleitung und adaptives Lernen in der Grundschule: Forschungsbezogene Beiträge [Learning process and adaptive teaching in primary school: Empirical findings] (pp. 15-32). Wiesbaden, Germany: Springer.

Massumi, M., von Dewitz, N., Grießbach, J., Terhart, H., Wagner, K., Hippmann, K., \& Altinay, L. (2015). Neu zugewanderte Kinder und Jugendliche im deutschen Schulsystem. In Bestandsaufnahme und Empfehlungen [Newly arrived children and youths in the German educational system: Status Quo and recommendations]. Köln: Mercator-Institut für Sprachförderung und Deutsch als Zweitsprache und Zentrum für LehrerInnenbildung der Universität Köln.

McTighe, J., \& Brown, J. L. (2005). Differentiated instruction and educational standards; Is détente possible? Theory Into Practice, 44, 234-244. https://doi.org/10.1207/s15430421tip4403_8.

Murray, D. W., Rabiner, D. L., Kuhn, L., Pan, Y., \& Sabet, R. F. (2018). Investigating teacher and student effects of the incredible years classroom management program in early elementary school. Journal of School Psychology, 67, 119-133. https://doi.org/10.1016/j.jsp.2017.10.004.

Murray, S. (2011). Declining participation in post-compulsory secondary school mathematics: students' views of and solutions to the problem. Research in Mathematics Education, 13(3), 269-285. https://doi.org/10.1080 /14794802.2011.624731.

Muthén, L. K., \& Muthén, B. O. (1998-2015). Mplus User's Guide (7th ed.). Los Angeles, CA: Muthén \& Muthén.

Newman, D. A. (2014). Missing data: Five practical guidelines. Organizational Research Methods, 17(4), 372411.

O'Connell, A. A., \& McCoach, D. B. (2008). Multilevel modeling of educational data. Charlotte, NC: Information Age Publishing, INC.. 
OECD. (2015). PISA results (Volume I): Excellence and equity in education. In Immigrant background, student performance and students' attitudes towards science. Paris: OECD Publishing. https://doi.org/10.1787 /9789264266490-11-en.

Opdenakker, M.-C., \& Van Damme, J. (2006). Teacher characteristics and teaching styles as effectiveness enhancing factors of classroom practice. Teaching and Teacher Education, 22(1), 1-21. https://doi. org/10.1016/j.tate.2005.07.008.

Paetsch, J., Felbrich, A., \& Stanat, P. (2015). Der Zusammenhang von sprachlichen und mathematischen Kompetenzen bei Kindern mit Deutsch als Zweitsprache. [Second-language support for immigrant children and students]. Zeitschrift für Pädagogische Psychologie, 29(1), 19-29. https://doi.org/10.1024/1010-0652 /a000142.

Paradies, L., \& Linser, H. J. (2008). Differenzieren im Unterricht [Differentiated instruction]. Berlin: Cornelson.

Pas, E. T., Cash, A. H., O'Brennan, L., Debnam, K. J., \& Bradshaw, C. P. (2015). Profiles of classroom behavior in high schools: Associations with teacher behavior management strategies and classroom composition. Journal of School Psychology, 53(2), 137-148. https://doi.org/10.1016/j.jsp.2014.12.005.

Piwowar, V., Thiel, F., \& Ophardt, D. (2013). Training inservice teachers' competencies in classroom management. A quasi-experimental study with teachers of secondary schools. Teaching and Teacher Education, 30, 1-12. https://doi.org/10.1016/j.tate.2012.09.007.

Raudenbush, S. W., \& Bryk, A. S. (2002). Hierarchical linear models (2nd ed.). Thousand Oaks, CA: Sage.

Rjosk, C., Richter, D., Hochweber, J., Lüdtke, O., Klieme, E., \& Stanat, P. (2014). Socioeconomic and language minority classroom composition and individual reading achievement: The mediating role of teaching quality. Learning and Instruction, 32, 63-72. https://doi.org/10.1016/j.learninstruc.2014.01.007.

Rjosk, C., Richter, D., Lüdtke, O., \& Eccles, J. S. (2017). Ethnic composition and heterogeneity in the classroom: Their measurement and relationship with student outcomes. Journal of Educational Psychology, 109(8), 1188-1204. https://doi.org/10.1037/edu0000185.

Rucinski, C. L., Brown, J. L., \& Downer, J. T. (2017). Teacher-child relationships, classroom climate, and children's social-emotional and academic development. Journal of Educational Psychology, 110(7), 9921004. https://doi.org/10.1037/edu0000240.

Seiz, J., Decristan, J., Kunter, M., \& Baumert, J. (2016). Differenzielle Effekte von Klassenführung und Unterstützung für Schülerinnen und Schüler mit Migrationshinterund [The role of classroom management and learning support for students with immigrant backgrounds]. Zeitschrift für Pädagogische Psychologie, 30(4), 237-249. https://doi.org/10.1024/1010-0652/a000186.

Simonsen, B., Fairbanks, S., Briesch, A., Myers, D., \& Sugai, G. (2008). Evidence-based practices in classroom management: Considerations for research to practice. Education and Treatment of Children, 31(3), 351-380.

Smit, J., van Eerde, H. A. A., \& Bakker, A. (2013). A conceptualisation of whole-class scaffolding. British Educational Research Journal, 39(5), 817-834. https://doi.org/10.1002/berj.3007.

Solzbacher, C. (2008). Was denken Lehrerinnen und Lehrer über individuelle Förderung? [What do teachers think about individualized teaching?]. Pädagogik, 60, 38-42.

Tanaka, J. S. (1993). Multifaceted conceptions of fit in structural equation models. In K. A. Bollen \& J. S. Long (Eds.), Testing Structural Equation Models (Vol. 154, pp. 10-39). Newbury Park, CA: Sage Publications, Inc..

Vaughn, S., Schumm, J. S., Niarhos, F. J., \& Daugherty, T. (1993). What do students think when teachers make adaptations? Teaching and Teacher Education, 9(1), 107-118. https://doi.org/10.1016/0742-051X(93 )90018-C.

Vogt, F., \& Brühwiler, C. (2014). Adaptive Lehrkompetenz für den Umgang mit Heterogenität [Adaptive teaching competences for teaching in heterogenous classrooms.]. Lehren \& Lernen, 8(9), 47-51.

Vygotsky, L. S. (1978). Mind in society the development of higher psychological processes. Cambridge, Mass.: Harvard University Press.

Wang, M. C. (1980). Adaptive instruction: Building on diversity. Theory Into Practice, 19(2), $122-128$. https://doi.org/10.1080/00405848009542885.

Wentzel, K. R., Muenks, K., McNeish, D., \& Russell, S. (2018). Emotional support, social goals, and classroom behavior: A multilevel, multisite study. Journal of Educational Psychology, 110(5), 611-627. https://doi. org/10.1037/edu0000239.

Yeh, S. S. (2010). Understanding and addressing the achievement gap through individualized instruction and formative assessment. Assessment in Education: Principles, Policy \& Practice, 17(2), 169-182. https://oi. org/10.1080/09695941003694466.

Publisher's note Springer Nature remains neutral with regard to jurisdictional claims in published maps and institutional affiliations. 